\title{
HIGIENE SANITASI PENGELOLAAN MAKANAN DI INSTALASI GIZI RSUD AJIBARANG KABUPATEN BANYUMAS TAHUN 2015
}

\author{
Ibnu Misbahul Munir'), Tri Cahyono ${ }^{2)}$ \\ Jurusan Kesehatan Lingkungan, Politeknik Kesehatan Kemenkes Semarang, \\ Jl.Raya Baturaden KM 12 Purwokerto, Indonesia
}

\begin{abstract}
Abstrak
Penyelenggaraan makanan di rumah sakit sebagai bagian dari sistem pelayanan kesehatan di rumah sakit yang mendukung upaya penyembuhan. Tujuan penelitian ini adalah untuk mengetahui Higiene Sanitasi Pengelolaan Makanan di Instalasi Gizi Rumah Sakit Umum Daerah Ajibarang. Metode penelitian yang di gunakan adalah deskriptif. Pengumpulan data dengan menggunakan observasi, wawancara dan pemeriksaan kualitas mikrobiologi makanan.. Hasil penelitian menunjukkan cara pengamanan bahan makanan (98,11\%), cara penyimpanan bahan makanan (87,5\%), cara pengolahan bahan makanan (96,55\%), cara penyimpanan makanan (88,89\%), cara pengangkutan makanan (96,15\%), cara penyajian makanan (100\%) dan Kualitas mikrobiologis makanan dari tiga sampel yang di periksa menunjukkan hasil negatif E.coli seperti bubur (0/gram sampel), tahu (0/gram sampel), Oseng sayur (0/gram sampel). Higiene Sanitasi Pengelolaan Makanan di Instalasi Gizi Rumah Sakit Umum Daerah Ajibarang memenuhi syarat sesuai dengan Kepmenkes RI No.1204 tentang Kesehatan Lingkungan Rumah Sakit. Disarankan untuk dilakukan penelitian lebih lanjut dengan jumlah sampel yang lebih banyak, variabel yang berbeda dan tempat yang berbeda.
\end{abstract}

Kata kunci : : instalasi gizi, pengolahan makanan, rumah sakit, kesehatan lingkungan

\begin{abstract}
[INFLUENCE OF DISTILLATION BABADOTAN LEAF (Ageratum conyzoides) AS REPELLENT ABOUT ALIGHT ENERGY OF MOSQUITO Aedesaegypti 2015] Dengue fever (DBD) in Indonesia became problem of public health and was endemic disease almost all provinces. One of alternative that potentially to control population of mosquito vector Aedes aegypti was used insecticides. Using of chemical insecticides have a negative impact on the body. Babadotan leaf contains saponin, flavanoida, fenol and oil volatile so it can be used as natural insecticide. The purpose of this research is to know effectiveness of distillation babadotan leaf (Ageratum conyzoides) as repellent of Aedes aegypti mosquito on the concentration of 20\%, 60\%, and 100\% during 3 hours. The method of this research is true experimental (real experiment) and data was analyzed with anova. The result of distillation babadotan leaf (Ageratum conyzoides) showed that there are difference number of mosquito which alight on concentration of distillation with significant value 0,000 $(<0,005)$ that mean there are difference number of mosquito that alight on various concentration that used. Based on this result, can seen that distillation of babadotan leaf (Ageratum conyzoides) can used as repellent of Aedes aegypti mosquito. Was suggested for researcher furthermore to do continuation experiment such as repellent of babadotan distillation was substituted with extract and only examine of effectiveness oil volatile as repellent of mosquito.
\end{abstract}

Keywords : Repellent, Aedes aegypti, Daun Babadotan Ageratum conyzoides, and environmental health

\section{PENDAHULUAN}

Persyaratan kesehatan lingkungan rumah sakit menurut Kepmenkes RI No. 1204 tahun 2004 ada 9 (sembilan) persyaratan dan disebutkan pada poin ke-2 romawi adalah persyaratan makanan dan minuman. Menunjukkan arti penting makanan dalam rangka mewujudkan derajat kesehatan setinggi - tingginya. Makanan akan menjadi lebih penting peranannya pada orang - orang yang sakit, seperti dirumah sakit umum sebagai fasilitas kesehatan yang memberikan pelayanan kepada semua pasien.

Salah satu pelayanan kesehatan di rumah sakit adalah Pelayanan Gizi Rumah Sakit (PGRS).
Pelayanan Gizi Rumah Sakit sebagai salah satu penunjang diselenggarakan oleh Instalasi Gizi yang bertujuan untuk menyelenggarakan bagi pasien. Penyelenggaraan makanan di rumah sakit dilaksanakan dengan tujuan untuk menyediakan makanan yang kualitasnya baik dan layak, sehingga akan memadai bagi konsumen (Depkes RI, 2003, h. 6). Pelayanan Gizi Rumah Sakit mempunyai peranan yang sangat penting dalam mempercepat penyembuhan pasien.

Penyelenggaraan makanan di rumah sakit sangat bergantung dari higiene dan sanitasi agar makanan tersebut tidak menjadi sumber penular penyakit bagi

1) Email : ibnumustikavanny@gmail.com

Keslingmas Vol. 34 Hal. 224 - 297 Desember 2015 | 281

2) Email : statistikan@yahoo.com 
manusia yang mengkonsumsi makanan tersebut. Pada kegiatan sanitasi makanan di rumah sakit, kebersihan bahan makanan yang diolah sebagai makanan untuk pasien rawat inap yang ada di rumah sakit serta sangat penting diperhatikan kebersihan dalam pembuatan makanan (Anggara, 2012, h.32). Mengingat bahwa manusia berperan penting terhadap kontaminasi makanan semua produsen makanan, penjamah, tukang masak, pelayan dan ibu rumah tangga mempunyai kesempatan untuk mengkontaminasi makanan melalui proses pengolahan, penyajian dan lain-lain (Depkes RI., 1998, h.198). Higiene sanitasi makanan adalah upaya untuk mengendalikan faktor makanan, orang, tempat dan perlengkapan yang dapat atau mungkin dapat menimbulkan penyakit atau gangguan kesehatan(Depkes RI., 2010, h.15).

Rumah sakit sebagai tempat kegiatan kuratif, rehabilitatip dan preventip, juga merupakan sarana pelayanan kesehatan yang dapat menjadi sumber infeksi dimana orang sakit dirawat dan ditempatkan dalam jarak yang dekat, infeksi nosokomial dapat terjadi pada penderita, tenaga kesehatan dan setiap orang yang datang kerumah sakit. Suatu penelitian di 10 rumah sakit pendidikan infeksi nosokomial cukup tinggi 6-16\% dengan rata-rata 8,8\% tahun 2010 (Balaguris, 2011, h.14). Data infeksi nosokomial yang dilaporkan RSUP DR. Sarjito Yogyakarta ratarata 7,95\% (Agus, 2011, h.23). untuk kasus nosokomial di Kabupaten Banyumas yang terjadi di RSUD Banyumas sebanyak 1 pasien $(4,2 \%)$ pada tahun 2012 (Apriyana, 2012, h.45). Infeksi nosokomial dapat menyebabkan diare, untuk pola 10 penyakit terbanyak pada pasien rawat inap di Indonesia. Diare menempati posisi teratas (Robert, 2013, h. 183). Kerugian yang ditimbulkan akibat infeksi ini adalah biaya yang dikarenakan lamanya rawat inap yang tentunya akan menambah biaya yang lebih banyak (Depkes RI, 1983, h.10).

Rumah Sakit Umum Daerah Ajibarang yang beralamat di Jalan Raya Pancasan, Ajibarang mempunyai 136 tempat tidur sehingga dilengkapi dengan Instalasi gizi yang memadai. Instalasi ini berguna untuk mengatur makanan pasca penyembuhan pasien yang ada di rumah sakit tersebut.

Bed Occupancy Ratio (BOR) atau angka penggunaan tempat tidur Rumah Sakit Umum Daerah Ajibarang adalah 56,41\%. Hal ini untuk Rumah Sakit Umum Daerah Ajibarang termasuk dalam kategori kurang memenuhi syarat, karena parameter BOR yang ideal untuk rumah sakit type $\mathrm{C}$ adalah $60-85 \%$.

Pelayanan Makanan di rumah sakit ini dengan SDM 4 orang ahli gizi dan 15 orang penjamah makanan.Memiliki fasilitas ruang yang cukup luas dan lengkap. Berdasarkan observasi peneliti terhadap penjamah makanan di runah sakit tersebut masih belum sesuai dengan persyaratan tentang makan dan minuman di rumah sakit, karena masih masih dijumpai 4 orang tenaga gizi yang tidak memakai tutup kepala, sarung tangan, masker dan sebagian ada yang tidak memakai celemek dan berbicara saat bekerja, sehingga kondisi ini memungkinkan terjadinya kontaminasi makanan dari mikroorganisme melalui tenaga pencuci atau alat makan yang digunakan dalam proses pemasakan dan penyajian.

Tujuan penelitian adalah mengetahui higiene sanitasi pengelolaan makanan yang ada di Instalasi Gizi Rumah Sakit Umum Daerah Ajibarang.

\section{BAHAN DAN CARA}

Jenis penelitian ini adalah penelitain deskriptif dengan menggunakan observasi, wawancara dan pemeriksaan laboratorium untuk memperoleh gambaran yang jelas dan nyata tentang sanitasi pengelolaan makanan di Instalasi Gizi Rumah Sakit Umum Daerah Ajibarang.

Pengumpulan data langsung diperoleh dari pengelolaan makanan pada Instalasi Gizi RSUD Ajibarang dengan menggunakan checklist, kuesioner dan pengujian laboratorium.

\section{III.HASIL DAN PEMBAHASAN}

\section{Hasil}

Penerapan higiene sanitasi pengelolaan makanan di Instalasi Gizi RSUD Ajibarang sebagai berikut :

1. Cara Pengamanan Bahan Makanan

Hasil pengamatan dengan menggunakan checklist menunjukkan bahwa pengamanan bahan makanan di Instalasi Gizi RSUD Ajibarang sudah baik dengan persentase $98,11 \%$. Penilaian yang kurang baik dengan persentase $1.89 \%$, karena penempatan bahan makanan seperti beras dan tepung masih diletakkan di lantai tanpa ada alas dibawah.

2. Cara Penyimpanan Bahan Makanan

Hasil observasi menunjukkan penyimpanan bahan makanan sudah baik dengan hasil persentase $87,5 \%$. Penilaian yang kurang baik dengan persentase $12,5 \%$, karena masih ada rak yang menempel di dinding dan tinggi rak dan pilet barang dari permukaan lantai kurang dari 30 cm. Penyimpanan bahan makanan pada lemari pendingin sudah tertata rapi dan suhu lemari pendingin sudah sesuai dengan peraturan yang berlaku dengan petunjuk yang tertera pada dinding ruang penyimpanan.

3. Cara Pengolahan Bahan Makanan

Hasil observasi menunjukkan bahwa cara pengolahan bahan makanan di Instalasi Gizi RSUD Ajibarang sudah baik dengan persentase $96,55 \%$. Penilaian yang kurang baik dengan persentase $3,45 \%$ dikarenakan ventilasi di ruangan pengolahan bahan makanan kurang, sehingga membuat keadaan di ruang pengolahan terasa panas dan kurang nyaman untuk pekerja serta masih ada penjamah makanan yang masih bercakap-cakap saat mengolah makanan.

4. Cara Penyimpanan Makanan 
Hasil observasi menunjukkan bahwa cara penyimpanan makanan di Instalasi Gizi RSUD Ajibarang sudah baik dengan persentase $88,89 \%$. Penilaian yang kurang baik dengan persentase $11.11 \%$, karena makanan jadi tidak tertutup dengan sempurna pada saat makanan di diamkan sebelum disajikan dan masih ada makanan yang dapat terkontaminasi oleh debu.

5. Cara Pengangkutan Makanan

Hasil observasi menunjukkan bahwa cara pengangkutan makanan di Instalasi Gizi RSUD Ajibarang sudah baik dengan prosentase 96,15\%. Penilaian yang kurang baik dengan persentase $3.85 \%$, karena penjamah makanan pada saat pendistribusian makanan tidak menggunakan sarung tangan.

6. Cara Penyajian Makanan

Berdasarkan hasil observasi menunjukan bahwa cara penyajian makanan di Instalasi Gizi RSUD Ajibarang sudah baik dengan persentase $100 \%$. Cara penyajian makanan menggunakan peralatan yang bersih dan disajikan oleh penjamah makanan yang sudah menggunakan APD dengan lengkap.

7. Pemeriksaan Kualitas Mikrobiologi Makanan

Pemeriksaan makanan dilakukan untuk mengetahui kualitas makanan yang disajikan oleh Instalasi Gizi RSUD Ajibarang untuk para pasien. Sampel makanan yang diambil adalah bubur, tahu dan oseng sayur. Semua sampel yang diambil dan diperiksa di Laboratorium Kampus 7 Purwokerto dan menunjukkan hasil negatif E.Coli.

\section{Pembahasan}

Penerapan higiene sanitasi pengelolaan makanan di Instalasi Gizi RSUD Ajibarang sebagai berikut :

1. Cara Pengamanan Bahan Makanan

Hal tersebut tidak sesuai dengan Kepmenkes RI No.1204 tahun 2004 tentang kesehatan lingkungan rumah sakit bahwa ketentuan penempatan bahan makanan sebaiknya jarak bahan makanan dengan lantai $15 \mathrm{~cm}$, jarak bahan makanan dengan dinding $5 \mathrm{~cm}$, jarak bahan makanan dengan langit-langit $60 \mathrm{~cm}$ dan bahan makanan dalam jumlah banyak dan belum langsung digunakan, maka sebaiknya diwadahi sesuai dengan jenisnya dan tertutup rapat. Hal tersebut harus di perhatikan oleh pihak instalasi gizi karena bahan makanan yang di letakan di tantai tanpa adanya alas akan dapat mudah diserang serangga dan tikus.

2. Cara Penyimpanan Bahan Makanan

Hal tersebut tidak sesuai dengan Kepmenkes RI No 1204 tahun 2004 tentang kesehatan lingkungan rumah sakit, seharusnya tinggi rak penyimpanan bahan makanan dengan lantai minimal $30 \mathrm{~cm}$ dan rak penyimpanan bahan makanan tidak menempel dengan dinding supaya tidak dapat di jangkau oleh serangga dan binatang penggangu menurut Kepmenkes Nomor 1098 tahun 2003 tentang syarat penyimpanan bahan makanan.

3. Cara Pengolahan Bahan Makanan

Tempat pengolahan makanan (dapur) sudah cukup baik, karena sebelum dan sesudah kegiatan memasak lantai diberishkan menggunakan antiseptik, kemudian terdapat cerobong asap yang dilengkapi sungkup asap, terdapat apar yang masih berfungsi dengan baik, perlengkapan pelindung pengolahan makanan, serta selalu mencuci tangan sebelum bekerja dan setelah dari kamar kecil hal tersebut sudah sesuai dengan Kepmenkes No.1204 tahun 2004 tentang persyaratan kesehatan lingkungan di rumah sakit. Sedangkan untuk ventilasi di ruang pengolahan bahan makanan yang kurang dan para penjamah makanan yang masih bercakap-cakap saat bekerja hal tersebut tidak sesuai dengan Kepmenkes No.1204 tahun 2004 tentang persyaratan kesehatan lingkungan di rumah sakit. Hal tersebut perlu ada perhatian khusus dari pihak rumah sakit untuk ventilasi ruang pengolahan makanan harus di tambah supaya tidak panas dan nyaman untuk para pekerja dalam bekerja.

4. Cara Penyimpanan Makanan

Penyimpanan makanan tersebut hanya bersifat sementara hanya untuk menunggu makanan lain masak dan jam penyajian tiba. Makanan yang disimpan tidak pernah lebih dari 45 menit. Hal ini tidak sesuai dengan Kepmenkes No.1204 tahun 2004 tentang persyaratan kesehatan lingkungan di rumah sakit, karena makanan yang tidak disimpan dalam lemari khusus dapat tercemar debu serta dapat mendatangkan serangga atau binatang penggangu.

5. Cara Pengangkutan Makanan

Hal tersebut kurang sesuai dengan peraturan Kepmenkes RI Nomor 1204 tahun 2004 tentang kesehatan lingkungan rumah sakit. Menurut Anwar et.all (t.th, h. 66) tenaga penjamah harus mempunyai personal higine yang baik.

6. Cara Penyajian Makanan

Berdasarkan data penyajian makanan di Instalasi Gizi Rumah Sakit Umum Daerah Ajibarang sesuai dengan Kepmenkes No.1204 tahun 2004 tentang persyaratan kesehatan lingkungan di rumah sakit karena penyajian makanan disajikan pada wadah yang tertutup dan sudah diberi sekat pemisah terhindar dari pencemar dan dalam keadaan bersih. Serta penjamah makanan yang menyajikan sudah berperilaku bersih dan menggunakan alat pelindung diri yang lengkap.

7. Pemeriksaan Kualitas Mikrobiologi Makanan

Pemeriksaan labolatorium yang tentu saja hasil tersebut sudah baik dan memenuhi syarat dengan Kepmenkes No.1204 tahun 2004 tentang kesehatan lingkungan rumah sakit yang menjelaskan bahwa standar E.coli dalam makanan khusus untuk Instalasi Gizi suatu rumah sakit 
adalah 0/gr sampel makanan dan 0/100ml sampel minuman.

Pemeriksaan sampel makanan di RSUD Ajibarang untuk pemeriksaan mikrobiologis makanan diperiksa 6 bulan sakali sebaiknya Instalasi Gizi RSUD Ajibarang mengadakan pemeriksaan mikrobiologis rutin setiap bulan sesuai dengan peraturan Kepmenkes No.1204 tahun 2004 tentang kesehatan lingkungan rumah sakit.

\section{IV.KESIMPULAN}

\section{Kesimpulan}

Higiene Sanitasi Pengelolaan Makanan di Instalasi Gizi RSUD Ajibarang dapat disimpulkan bahwa keadaan hygiene sanitasi makanan di RSUD Ajibarang sudah baik berdasarkan aspek sebagai berikut : Cara Pengamanan Bahan Makanan sudah baik dengan persentase $(98,11 \%)$, Cara Penyimpanan Bahan baik dengan persentase $(87,5 \%)$, Cara Pengolahan Bahan Makanan sudah baik dengan persentase( 96,55\%), Cara penyimpanan Makanan sudah baik dengan persentase $(88,89 \%)$, Cara Pengangkutan Makanan sudah baik dengan persentase $(96,15 \%)$, Cara Penyajian Makanan sudah baik dengan persentase $(100 \%)$, dan Kualitas mikrobiologis makanan sudah memenuhi syarat dari hasil pemeriksaan laboratorium menunjukan sampel bubur nasi 0/gram sampel, tahu bacem 0/gram sampel, oseng sayur 0/gram sampel pada semua sempel yang diambil negiatif E.coli.

Saran

Peneliti menyarankan untuk dilakukan penelitian lebih lanjut berdasarkan faktor lainnya, variabel yang berbeda, jumlah sampel yang lebih banyak, tempat yang berbeda dan tetap berhubungan dengan higiene sanitasi pengelolaan makanan.

\section{DAFTAR PUSTAKA}

Anwar, et.all, Pedoman Bidang Studi Sanitasi Makanan dan Minuman pada Institusi Pendidikan Tenaga Sanitasi, Jakarta; Depkes RI.

Aritonang, Irianto dan Priharsiwi, Endah. 2009, Manajemen Penyelenggaraan Makanan dan Asuhan Gizi, Yogyakarta; Penerbit Lutika.

Azrul Azwar, 1986, Pengantar Ilmu Kesehatan Lingkungan, jakarta; Mutiara Sumber Widya

Boy Subiroso S, Agus Kharmayana R, Sri Sukmaniah, 2011, Sanitasi Makanan dan Minuman Menuju Peningkatan Mutu Efisiensi Rumah Sakit, Jakarta; Salemba medika.
Bulgaris, Agus, 2011, Dalam Nih : Data Kasus Infeksi Nosokomial, http://thesis.umy.ac.id/datapublik, Tanggal akses : 16 Januari 2015 Jam 20.00 WIB.

Darmadi, 2008, Infeksi Nosokomial: Problematika dan Pengendaliannya, Jakarta; Penerbit Salemba.

Depkes RI., 1998, Pedoman Pengawasan Kualitas Makanan, Jakarta; Ditjen PPM \&PLP Depkes.

Depkes RI., Ditjen PPM \& PL, 2004, Keputusan Menteri Kesehatan RI No. 1204/Menkes/SK/X/2004, Kesehatan Lingkungan Rumah Sakit.

Depkes RI., Direktorat Penyehatan Lingkungan, 2010, Kumpulan Modul Kursus Hygiene Sanitasi Makanan dan Minuman, Jakarta; Sub Direktorat Sanitasi Makanan dan Bahan tambahan pangan.

Dessy, Apriliana, 2012, Hubungan Penggunaan Alat Pelindung Diri Perawat, http://digilib.shb.ac.id, tanggal akses : 16 Januari 2015 Jam 18.20 WIB .

Dinkes Prov., Jateng, 2005, Cara Produksi Makanan yang Baik, Jawa tengah; Dinkes Prov Jateng.

Profil RSUD Ajibarang, 2014, Bor Rumah Sakit Umum Daerah Ajibarang, http://www.findthebest.co.id, tanggal akses : 15 Januari 2015 Jam 14.30.

Robert Imam, 2013, Infeksi Nosokomial Sebabkan Diare hingga Penyakit Kulit, http://www.okezone.com, tanggal akses : 16 Januari 2015 jam 19.00.

Suharsimi Arikunto, 1998, Prosedur Penelitian, Jakarta; Rineke Cipta.

Tri Cahyono, 2014, Pedoman Penulisan Proposal Penelitian dan Karya Tulis Ilmiah/Skripsi (Edisi Revisi Ketiga, Jakarta); Pusdiknakes Depkes RI.

Undang-undang Republik Indonesia., Nomor 44 tahun 2009, tentang Rumah Sakit. 